\title{
MANIFESTO: Theatre for the Dead
}

\section{(ii)gps.psi-web.org/issue-3-2/gps-3-2-9}

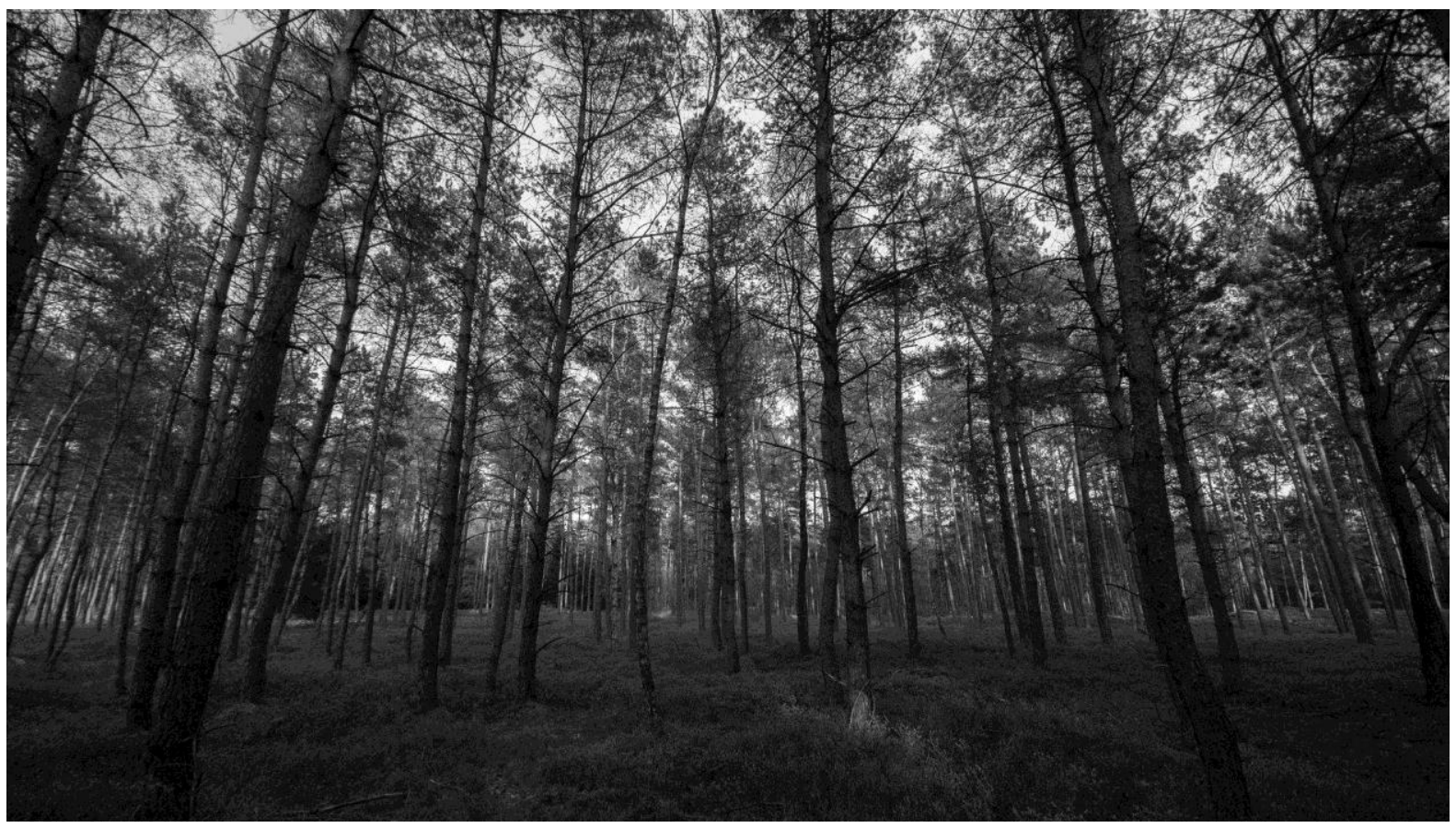

Danowski, Christopher. "Manifesto: Theatre for the Dead." Global Performance Studies, vol. 3, no. 2, 2020, https://doi.org/10.33303/gpsv3n2a9

\section{Christopher Danowski}

University of Portsmouth

Opening $^{[1]}$

Because we cannot sleep.

Because we are haunted, because there are spectres, and they might be metaphors, but those metaphors might very well be spectres in disguise.

Because we miss someone.

Because we love to hear "I miss you."

Because an empty chair is always inhabited.

Because a mask covers a face. And everyone wants to see the face under the mask. If you have a mask in the first act, you have to show the face in the third act.

Because we remember the dead, and that was not so common when I started writing this in southeast England in 2019. Now it's April 2020, and our memories have been refreshed.

Because there are more perspectives in any interaction than the living perspective.

Because this century was supposed to be the one where we had learned all the lessons from the past century, and it seemed as though it was well understood that we would learn from our pasts and not repeat ourselves. 
And it is obvious by now that as a whole, we (the living) are slow learners and could certainly use the advice.

And because we are caught in these repetitions, and we are helpless to stop them, we are restless, and, when we are restless, the dead are restless. Global crises make us all restless, the living and the dead (because the world of the dead can be a mirror to the world of the living). This means that the souls that were put to rest are made restless again because clearly these are times of crisis.

Because marketing departments are insisting that we need to expand our audience base. We wonder why that base has to be limited to the living. ${ }^{[2]}$ We wonder if there is a concession price, a discount, for the dead. We want to consider expanding our audience base to include the base that is always already there, the first step of which is to start paying more attention to them (and by them, I mean, eventually, us).

This manifesto is an attempt to carve out some thoughts on how to become aware of that audience because so much of theatre training involves kinaesthetic response to visible, audible, and/or tactile stimuli; perhaps we can learn better how to perceive invisible audiences and expand our understanding of what constitutes responding. Perhaps our developing skills in learning how to encounter each other and make theatre without the same kinds of stimuli can be somewhat transferable, that the romance languages of the virtual will give us necromantic tongues.

Because we are all constructions of texts but also constructions in material form that contain and reflect all the lives that are no longer (including star stuff and elements and all the romantic things that make us stare at the moon and cry like dogs). Which is to say: we are composed of the words and matter of those who came before. Everything we do is a continuation of the ancestors, and one day we will also be ancestors.

What is necessary are some ontological leaps, or maybe better, shifts in the imagination, or better even, shifts in the imaginary. ${ }^{[3]}$ Through these shifts, we come to this: The Theatre for the Dead.

In one definition, a manifesto is an angry gesture made with the fist, and I suspect that the lines on this fist might provide a very useful map. This manifesto is an articulation for the theatre-maker who comes along wondering if there are any useful maps for a theatre for the dead. Your fist is your own map, then, connecting you to your own dead. For the purposes of this manifesto, I want to start with a map that might inspire you to find your own map. My own contexts for understanding the relationship between the dead and the living come from experiences as student and practitioner of Afro-Cuban ritual practices. I was initiated into Palo in 2007 and Lukumí in 2008; the world of the dead in Palo opened up first, and this was my first map, so I'm drawing from that one for the purposes of this manifesto. Below is a Kongo cosmogram indicating the Four Moments of the Sun (Janzen and MacGaffey 34). ${ }^{[4]}$ This cosmogram offers a kind of map for the soul, a circle that represents continuity through lifetimes and generations. Imagine two lines forming a cross and a disk at each of the cardinal points. The lines divide the left and the right, the above and below. 


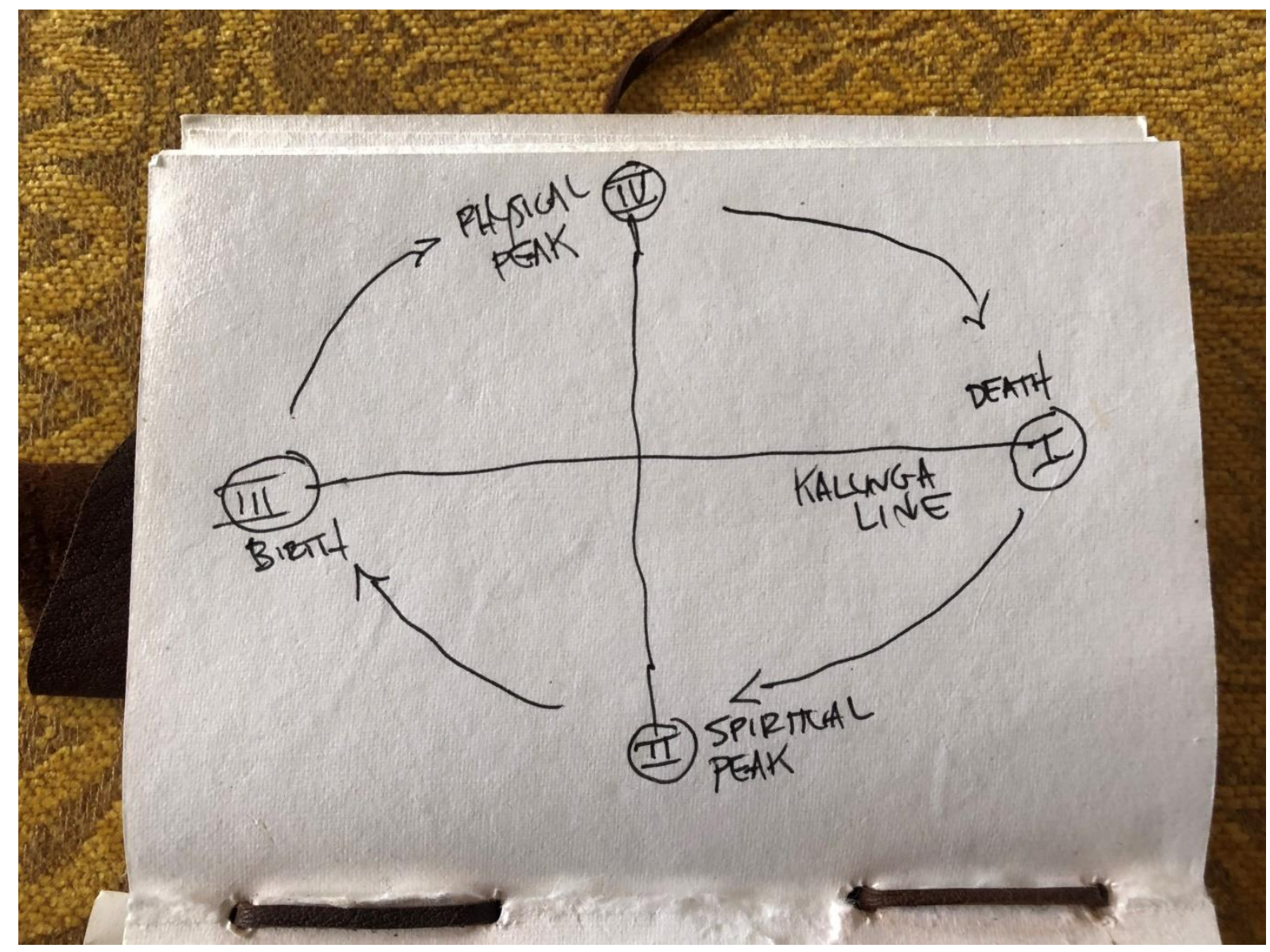

The line dividing the above from the below is the Kalunga line (the dividing line between the world of the living and the world of the dead). This manifesto is constructed in accordance with this cosmogram, four moments of thought toward a theatre for the dead to mirror the four moments of the sun. Mirrors are important in this.

Moment One is passing from above to below, or dusk, which is to say, the moment of death. In this section, I will discuss why theatre is an already haunted form and lay out the basic framework for a hauntology of theatre. Moment Two is the nadir, or bottom, of the cosmogram, which signifies midnight (or the height of spiritual powers, when the dead are at their best). This is where I will discuss the political influences and ritual contexts for Theatre for the Dead. Moment Three is the entrance from the lower to the upper world, or the moment of birth, which is dawn. This is where I bring in methods for making the work and discuss how practice-led research is embodied practice. Moment Four is noon, the apex of the cosmogram, when the living are at the height of their physical power, and this is where I make final prescriptions, moving into a space where the living and the dead haunt each other. This Four Moment structure is both circle and spiral, a capture of a moment in time, but without beginning and without an end, suggesting the continuity of the conversations and work between the dead and the living. ${ }^{[5]}$

\section{Moment One: Death / Dusk / Disembodiment}

$++++[6]$

In September, 2013, I lost my dad. He'd served in the Air Force in the early 1960s and, like my mom, became politically active in anti-war and anti-racism movements afterwards. In 1971, he was 
diagnosed with Multiple Sclerosis. (At the time, he was given five years to live, so living for forty years or so afterwards is, I think, a pretty good run).

In grad school in the early 1990s, I met some artist-scholars who had recently been through initiations in both Lukumí and Palo. These were my first teachers in these traditions, and they became my first godparents. From my first experiences with these ritual practices, I understood that my cultural upbringing and education did not prepare me for this, and if I continued on this path, it would mean a life-long education in decolonization. I learned to see African and Latin influences in the culture, philosophy, music, and other art forms in the U.S.

In my ritual education, one of the first big moments involved a healing that my godmother performed on me that was related to my father's health. This was a Palo ceremony, the details of which I cannot spell out here. It involved a ritual burial, and it taught me to think about death in a new way, one that had very little to do with the Judeo-Christian conceptions of death that I had been raised with. Around this time, my grandfather, who had been recently deceased, started to appear in my dreams.

By the time my father did physically die, I had been thinking about his death, having had preparation for it many years before. He died while I was writing a piece called romeo\&Juliet/VOID. This would be the first piece I would develop for my doctoral thesis, working with a group of actors I knew well, to be performed in my living room for a very small audience. It didn't occur to me that we could make theatre for the dead, not yet, but it did seem reasonable to approach this performance as if he were listening and seeing. The play opened with my dad's last words ("Are we going back?"). The performers were following a new methodology I was developing with their participation. We were working toward light states of trance, connecting to ancestors. The performance was conceived as a kanga (a word from Palo ritual practices, which translates roughly as a "work" or a "spell," whose etymological roots signify "tying"). The performance contained spoken and somatic references to tying, and the video here is excerpted for these specific references. It also describes and illustrates the methodology. The aesthetic for the performance was rough and low-budget, and the video definitely reflects that lo-fi aesthetic but also aptly demonstrates some of the experience of performers and audience.

\section{Moment One A: Theatres of the Dead}

The "where" of where we are heading depends upon the "where" we are now, and a theatre for the dead takes place in a specific kind of space. Theatre tends to happen in another space and often in an underworld. Like in stories of Persephone and Eurydice, this underworld is a neutral space, not hell, but a mirror to the world on the surface, containing the signs of an unbridgeable gap. "Space combined with memory defines place" (Lippard 10). This space is haunted by memory. Does this mean creating a performance that summons ghosts or creating a performance to silence them? Or something else? Something that resists tautology, something in between the living and the dead, something that exists on the line between the living and the dead, not a space of closure, but a space to inhabit, a space that opens up in time.

Schechner's notion that performance is "ritualized behaviour conditioned and/or permeated by play" (Schechner 52), along with Victor Turner's work, is useful (and foundational for how the relationships between performance and ritual are discussed in performance studies). There is enormous slippage between the terms (and considerable scholarship on this very slippage), and my aim here, in the video documentation accompanying this text, is to expand the slippage, so that it might become a performance of repetition permeated by play. The digital space becomes a medium, 
drawing on the connections between spirit mediums and digital media. In photography there is what Behrend calls "the stop of death" (Behrend 220), where the figure is captured in motionlessness. In video projection, the figures are captured in motion. The digital space then becomes more slippery. It opens up.

Performance and ritual, for me, exist in spaces that open up in time, or at times that open up in spaces: crossroads or intersections. ${ }^{[7]}$ This line is the Kalunga line. ${ }^{[8]}$ The Kalunga line comes from Palo cosmology and stands as the literal and metaphorical water mark separating the world of the living from the world of the dead. The line is made more porous in theatre and performance, a liminal space where ritual and digital technologies make it possible that "the dead are no longer sequestrated" (Walter 227).

The "where" is a present that is in between past and future but somewhat unstuck in time,,$\frac{[10]}{}$ somewhat hauntological. $\frac{[11]}{A}$ theatre of remembrance. $\frac{[12]}{}$

This is not new. Margaret Atwood argued that "all writers learn from the dead" (Atwood 159), ${ }^{[13]}$ and Howard Barker writes that "death is the preoccupation of great art even when it is not the subject of it" (Barker). The director is sometimes called psychopomp, and the psychopomp is, literally, the one who takes the living to the land of the dead. There are plenty of predecessors ${ }^{[14]}$ and contemporaries.

The dead haunt everything, of course, but this section is examining the traces of the bodies left in theatre. The dead are so ubiquitous in performance that Herbert Blau refers to Hamlet's Ghost as the ghost of a ghost (Blau 212), always already a citation of previous citations. Marvin Carlson notes this as well, referring to "the sense of coming back" (Carlson 2) as a starting point for a lexicon of the various kinds of ghosting and ghosts that haunt the stage. The notion of the revenant, the one who comes back, reflects the repetition of the rehearsal room with the repetition of memory with the repetition of the cycle of life and death and has obvious metaphorical resonance in theatrical practice. Peggy Phelan writes of the theatre as a form that is rehearsing "its disappearance" (Phelan 146). Bert $\mathrm{O}$. States, in his phenomenology of acting, extended the metaphor of revenant by applying it to the process of inhabiting a character. If a character "manifests itself as a repetition or a self-continuation rather than as a change" (States 8 ), this repetition becomes a place where the dead and the living are simultaneous, the injection of the past into the present (and vice-versa). Hamlet contemplates his own mortality while holding the skull of a friend. As Critchley and Jamieson suggest, Hamlet's contemplations and melancholy come from an inability to mourn the Ghost (Critchley), $\frac{[15]}{1}$ the literal ghost that haunts the play. This ghost haunts Hamlet in every way.

Beckett's ghosts are born astride a grave; Abdoh's Orpheus and Eurydice are forever here and not here. Patricia Ybarra, writing about Victor Cazares' Ramses II, discusses a character who becomes a corpse and continues to occupy the stage, depicting a "refusal to be disappeared" (Ybarra 177), so that the dead are never removed from the political (but instead they animate or are animated by it). Ana Mendieta burns her traces into tree trunks and on the ground, a living trace in the present that is destined to become the trace of a body that once was here. The body is mortal and performance is a glimpse of this mortality in the present moment.

Sometimes the ghosts peek in; sometimes they are the centre and the periphery. In Tadeusz Kantor's theatre of death (Kantor), the mannequin becomes the shell of the ghost, a presence haunting the presence the living actor. ${ }^{[16]}$ The cultural practices of honouring the dead (like Halloween, Samhain, the Days of the Dead in the Americas, Forefather's Eve in Poland, and Yoruba Egungun masquerades) are simultaneously living traditions and artefacts of an ongoing 
conversation. Like the European colonists in Soyinka's Death and the King's Horseman (Harding 112) who radically misunderstand the traditions, any generic performance for the dead, without knowing their names, their histories, is arrogance. This plays out as what Sayak Valencia calls capitalismo gore (Valencia), where popular entertainment whose subject matter is the borderland between the U.S. and Mexico anonymizes the bodies of the dead as necessary casualties in the participation in a global economy. If globalism and neoliberalism have made it possible to gloss over these details and distinctions so thoroughly that we have effectively removed the ghost, then it is time to bring back the ghost.

\section{Moment One B: Hauntologies}

This leads to what I am calling hauntology, although I use the term a little differently than it's been used in the past half century or so. Derrida used the term hauntology in his Spectres of Marx to refer to an ontological state where "one can never distinguish between the future-to-come and the coming back of a spectre" (35). Mark Fisher continued in this vein and wrote about hauntology in the sense that the present moment is haunted by ideas of a future that never happened or haunted by the shadow of a "near future" (Fisher 22). $\frac{[17]}{}$ Hauntology is also a term applied to the field of performance studies by Diana Taylor (142), where Derrida's persistence of revolution is that which surrounds the trauma embedded in the contextual fabric of the Americas.

I am using the term to refer to the ghosts and ghostings that are peculiar to performance, in particular as they emerge through the frictions inherent in a collision of ontological and cosmological systems (Western theatrical performance traditions and African-derived conceptions of spirit possession). What kinds of ghosts and ghostings happen in ontological systems where reality is coconstituted by the living and the dead, where both experience tensions between one identity and another? Alice Rayner writes "theatre itself is a ghostly place in which the living and the dead come together in a productive encounter" (Rayner xii), and this echoes other similar claims from theorists and practitioners who are writing from a particularly Western sensibility. I am pulled in several directions. There is the pull from my Western theatrical and intellectual training that tells me to understand the idea of ghosts and ghosting in a metaphorical sense. In my ritual training, the ghosts speak. The ghosts can also serve metaphorical functions for the practitioner. They are often both and more, like the one in Hamlet, who is very specific about what he wants, and he is also serving as a literary device. This tension is not mine alone but common for someone both inside and outside varying ontological formations, and this tension is where gaps arise. Rayner describes these as "the gaps that arise in the process of imitation and repetition" (42), and perhaps I am asking for a subtle shift of attention from the gap to the materiality of the ghost itself.

\section{Moment Two: Spiritual Peak / Midnight / Being Ghostly}

$+++0$

I moved from Phoenix in the U.S. to Portsmouth in the U.K. in October 2018. The day after I found out that I was moving, I also learned that my friend Morgan had taken her own life. We'd been in love and had a very short run a few years before that, and that was one of those haunted loves, where we wrote each other in secret long after it was over. She was also the inspiration for a couple of plays, but at the time of her death, we hadn't been in touch at all for a year or so.

The day after I arrived in the U.K., I got news that an old friend named Rich had taken his life back in Arizona. 
I dreamed about him a week later, and it felt like a goodbye. I didn't dream of Morgan. I wanted to say goodbye.

With director Erika Hughes and media designer Boyd Branch, I wrote, and we developed a theatre piece called Scattering Salt that was performed at the Brighton Fringe. Our venue was at the Old Police Cells Museum in the sub-basement of Brighton's City Hall in a space that had served as a jail in Victorian times. This work was the goodbye to Morgan, where I was publicly saying out loud the things I wanted to tell her. The play ends with a big dance party, and I know she would want to be remembered through a big dance party.

In the creation of the piece, we drew together elements of spoken word, movement, and projected image to create a kind of jazz. We wanted to put the audience into a state of consciousness where they were able to watch a play while contemplating their own dead, and the performance was followed by a collective goodbye ritual. Based on the responses from the living, it was effective. In terms of the dead, it still felt unfinished. The following Halloween, we presented a new version in Portsmouth for the DarkFest festival. In this version, we took out all the media and arranged the scenes in random order that would be determined by the audience randomly drawing tarot cards. During the last performance, I gave a tongue-in-cheek knock on a table, imitating the Victorian mediums of the nineteenth century and was surprised to hear a knock back.

Even though I am initiated into both Palo and Lukumí and do have a more or less quotidian kind of contact with the dead, these uncanny moments are very powerful. Not because they tell me the dead are listening. I know they're listening. They're powerful because they tell me that I still want a feather of proof.

The video below is an excerpt from the first version of Scattering Salt. The audio is removed to make room for ghostly voices, to create a tension in the viewer, so that you might have something of the experience the spectators had when watching the performance in a basement prison in Brighton. (I'll discuss sound more in the next section).

The video is an attempt to capture a performance with multiple ingredients from that performance. (Video and text and the editing suggests something of the rhythm of the performance). The video's multiple ingredients suggest a prenda. In Palo ritual practices, spirits from the pantheon of the dead (known as muertos) are ritually mounted in containers, often large iron pots. These pots contain dirt, herbs, and other ingredients that are important or useful for the pot's particular muerto. It is important to distinguish here between prenda and muerto because they are not the same. The prenda is actually a house for the muerto, a resting place. The play text, the live performance, and even this writing are also prendas. $\frac{[19]}{{ }^{2}}$ They don't contain the muerto; they just provide a home.

The manifesto is also a prenda. The ingredients are often particularly charged (some of them quite literally), so they can speak to each other and react to each other. I am not in any way trying to make any kind of universal prescription in terms of how to contact the dead, only suggesting that theatre can be created with the dead in mind.

The dead have in common the mutual fact of their own death, and the living share the mutual fact that we have not yet died. We are also living in a space and time between colonisation and decolonisation, where colonial epistemologies act as barriers to communication. At the risk of sounding hopelessly naïve and optimistic, is it possible that the various ontologies of the dead could work as a kind of Creole garden, mutually supporting each other, even with their problematic histories (and problematic presents and more than likely problematic futures)? What kinds of conversations become possible when the living speak to the dead, and when we attempt to listen? 


\section{Moment Two A: Creolozation}

Edouard Glissant's idea of creolization, $\underline{[20]}$ where plurality of cultures in times of accelerated communication can produce new modes of relation, offers an alternative to globalisation. An example, or metaphor, for how creolization functions in human societies is the Creole garden. The Creole garden was kept secret from thieves and slaveowners so the slaves could feed themselves because they were malnourished. These gardens contained radically diverse plants that, instead of strangling each other, serve to protect each other. The seeds flourish based on the principle of the rhizome, growing outwards in multiple directions, communicating with multiple parts of the world. This follows "the principle of distribution" and serves as a metaphor for human relations, as it demonstrates that our diversity protects us (Diawara).

Creolization can mark present moments in history as places where multiplicity and hybridity destabilise and de-territorialize stale cultural contexts for relating to the dead. Part of knowing, of learning, of meeting each other, is a certain jouissance in difference and nuance, interculturally and hauntologically. Paul Gilroy, in considering changes in autobiographical writing, spoken word, music, where they are becoming new forms of artistic and cultural expression, notes that these forms "have overflowed from the containers that the modern nation state provides for them" (Gilroy 40). As the garden metaphor implicitly connects to the ground and the dead and cultural forms draw upon a dialogue between the dead and living, Creolization is already embedded within hauntology.

\section{Moment Two B: Ritual Ontologies}

My experiences with the dead come from three ontologies. First is the Western intellectual and cultural traditions in which I was raised (though it's difficult and maybe ridiculous to say this is one ontology, or to reduce any ontology to one and then extend it into a generalisation). Then there are the two ontologies that come from Lukumí and Palo. I've been a practitioner since 1993, and, in 2007-2008, I was initiated into both ritual systems. Lukumí (a.k.a. Santería, La Regla, Ocha) draws from Yoruba tradition and developed in Cuba during the transatlantic slave trade before moving into the Americas and the world at large. It is an initiatory tradition that is in large part drawn from natural forces and the ancestors. Ancestors are at the root of everything, and they're acknowledged in most ceremonies and rituals before directing attention to the Orishas. Palo has a similar origin in Cuba to Lukumí but is derived from Kongo traditions. Palo also draws on natural forces and the ancestors, but the focus is more sharply toward the ancestors, called, collectively, the muertos. Although both traditions include an active and ongoing relationship with the dead, influences from the ontological world/s of Palo come into play in how I conceive of the Theatre for the Dead.

In one sense, the dead can be conceived of as a mass of relatively undifferentiated ancestors, which can be all the dead who ever lived (and died), or the local ghosts. In another sense, the dead are specific, ones invited into the space either by name or some other invocation. In Ochoa's conception of the Palo cosmological universe, these can be called the ambient dead (the undifferentiated ancestors) and the responsive dead. ${ }^{[21]}$ In ritual and performance practice, these are very different things and require different approaches; however, they are also very slippery (just as in ritual and performance practice the distinctions between the living and the dead become slippery). $\stackrel{\text {.22] }}{\underline{2}}$

This slipperiness of category is also part of the phenomenological experience of practitioners in ritual practice. Both Michael Atwood Mason and Henry John Drewal have developed new terminology for articulating subjective experience in Yoruba and Yoruba-derived systems, and these terms refer to ritual ways of knowing. ${ }^{[23]}$ Mason refers to a state of consciousness he calls "reflective flow" (Mason 102), where, during intensely focused ritual activity, one becomes aware of their own subjectivity 
and objectivity simultaneously. Drewal re-defines semiotics into his analysis of Yoruba ritual and changes it to "sensiotics" (Drewal 1) to allow for depth of experience that is beyond the rudimentary discursive, logocentric ontology of the academic Western world. These are ritual states of consciousness that can be considered to be outside of time (in illo tempore (Eliade) in Eliade's conception), but they simultaneously engage with contemporary political reality.

\section{Moment Two C: Synthesis}

In this political reality, the present is one that is weighted with the memory and memories of the dead who carry the trauma of the transatlantic slave trade, so that even in the ritual forms, the past and present continue to interrupt each other: "When an entire repertoire of physically habituated motor responses and ways of responding, such as religious dance and ceremonial spirit possession, are modelled on and perpetuate an earlier African tradition, the effect of calling them up is, among other things, to recreate the past and participate in it" (Brandon 148). Joseph Roach's idea of surrogation, that culture reproduces itself through substitutions that do not quite fit (Roach 2), speaks specifically to how the present and the past are speaking to each other in funerary performance (and other performances of memory), and that in this way memory depends upon forgetting. With Brandon, in ritual "the main effort is not only to make both the past and the present 'best' but to keep the past and the present aligned, like two mirrors facing each other" (Brandon 183). This complicates Western notions of past and present, challenging the notion of the ghost as fixed (or resolved). The ghost is, like the past, as unresolved as the living and just as slippery. Christina Sharpe writes that "We must become undisciplined", seeing "being black in the wake as a form of consciousness" (Sharpe 13), where the wake is the history of slavery and its history lives in the present. Living in the wake is to exist in multiple places and times at once. The challenge for both the living and the dead is in entering a more contingent and fluid relationship with time.

This calls for a radically recentered notion of the traditional Western ontologies of the dead. ${ }^{[24]}$ The notion of haunting is itself haunted, and one of the more pervasive spectres comes from Victorian mediumship (more specifically the charlatans and frauds that this period draws to mind). This has become such a part of the imagination of the west(Bell) that the very idea of ghosting itself needs decolonizing. I don't have the lived experience of blackness. I am from the U.S. and grew up with ideas of haunting, of the dead, and even memory as filtered through colonizing lenses. (See for example the influence of French educator and founder of Spiritism on mediumship practices in the Americas). Through participation in Lukumí and Palo ritual practices I was introduced to embodied experiences where the dead are not dead and gone and where haunting often precedes knowing and remembering. In certain moments the dead are viscerally present and active in the lives of the living. These are specific ontologies that see the dead as present, although the dead so seem to be present in most cultural traditions, or at least they show traces of this. Enough so, that I would make the claim that connecting with one's own dead, one's own lineage, is a way into another kind of experience that necessitates a reconsideration of how the past and present relate to each other. In Palo, the muerto takes on some aspects of the living, being involved in the present of the practitioner, and the practitioner, in turn, goes through initiatory rituals that make them a little dead. Talking to the dead, making theatre for the dead, is understanding that the living and the dead carry something of the other already, enough to start a conversation.

\section{Moment Three: Birth / Dawn / Embodiment}

$$
000+[25]
$$


Before I moved to the U.K., just a week or so before I got the news that I had a new post at a university there, I was with my godfather and my godsister in a back yard in California. We were trying to keep the dogs away as we pulled a forty-kilo iron pot from out of the ground. It smelled of earth and meat and rotting herbs; it smelled like death. We took the pot inside and got it ready so that I could put it in the back of my car and drive it home to Phoenix. When my elders were doing the final preparations and talking with my muerto, I started to shake up and down one side of my body. I mention this because this shaking is one of the embodied practices where we get to know each other.

When I got the prenda back to Phoenix, I moved the prenda from the car to the storage shed outside of where I lived. (Prendas should be kept outside the house, if you have room). I kept it locked in the shed, visited it every morning (taking care to keep my very curious dog from getting too close) and got used to the fact that the smell of death was only intensifying in the summer heat.

When I found out that I had gotten the job I applied for, I was thrilled and simultaneously wondering how in the hell I would get my prenda across the Atlantic. But I remembered that these are traditions that move around the world, through the histories of slavery and other forced migrations, and I understood that I was privileged to have the problems I had and have.

England is a small country compared to where I used to live, and the living spaces are smaller than what I was used to in Phoenix, but my first flat had a nice little storage area under the stairs. When my prenda (and Orishas) arrived by boat two months after I arrived, I had room. My second flat is smaller, with no storage space, and as practitioners find, you have to make do with what's available. You might think that sleeping with a prenda in your room would give you weird dreams, and you would be right. I found myself trying to resolve different kinds of consciousness, including a waking one where I play the role of an educator and academic and a dream one where there is more there than there used to be.

My godsister, Rayna Russom, is an experimental electronic musician, and we've had hundreds of conversations about how these ritual practices influence our art practices. She introduced me to two phenomena from electronic music that serve for me as methods and/or metaphors for ritual consciousness and creolization: the difference tone and the ghost frequency.

\section{Difference Tone}

Rayna explained the difference tone as something where, if you play two very different tones, the mind of the receptor will have to resolve these by creating a new tone in their consciousness. They hear it as a single tone, although strictly speaking, it only exists in their head. She utilizes this in her performance work, maintaining simultaneous tones that need the listener's consciousness for resolution. This is one of the peculiar aspects of electronic music, coming from a legacy mapped out by Adorno, who wrote that the gramophone is a "border marker between two periods of musical practice" (Adorno 52). The machine plays the recording, but the tone is empty and "only filled by the hearer" (55). This experience of trying to resolve the tones, resulting in a new tone that exists in a clash of material conditions, is akin to ritual flow, where attention and concentration to a multiplicity of stimuli produces a new hybrid.

\section{Ghost Frequency}

The ghost frequency is another hybrid product of electronic music, referring to "sounds that appeared on recordings due to signal interactions that resulted from 'improper' mixing" (Russom, https://soundcloud.com/blackmeteoricstar/sets/black-meteoric-star-ghost). Adorno, 
reflecting on Benjamin's conception of aura ("the presence of that which is not present") writes that "the culture industry is defined by the fact that it does not strictly counterpose another principle to that of aura, but rather by the fact that it conserves the decaying aura as a foggy mist" (Adorno, The Culture Industry: Selected Essays on Mass Culture 102). This foggy mist recurs in Brian Kane's notion of acousmatic sound (when the source of the sound is invisible to the listener), reflecting again to the beginning of recorded music with the phonograph, which could reproduce the voice and therefore animate the dead(Kane 183).

The difference tone can serve to illustrate embodiment's role in ritual knowledge, but the ghost frequency is an embodiment without the human. Both can contribute to a feeling of ghostliness, to perceptions of an ephemeral presence. The technologies of theatre and performance, text and movement, recorded and projected media, are also ideal technologies that play amongst themselves but also engage the perceptual tools that the spectator brings into the space. This actively engages with states of consciousness that are amenable to communication with the dead.

These aspects of recorded sound work together to create an experience for the listener that is a kind of time travel; different time signatures and tones exist simultaneously, aware of each other, speaking to each other. This is sometimes felt in performance as a sense of emergence. An illustration this is in the video below with Heather Lee Harper performing in Hotel Athena, performed in Phoenix, Arizona in 2016. Hotel Athena was an interactive installation piece with the audience moving through a house. They were invited to walk through rooms where actors repeated sections of scripted performance, video memories were projected on sheets and walls, a disembodied voice narrated a story of lost love, and, at one point, there was a firedance ritual in the back yard. Harper played the central figure, an enigmatic character who is both muse and ghost. She appears as a dancer in video, as the primary subject of memory video montage, and as the actor delivering the final monologue of the script, included here. There are three kinds of performance in this video: the spoken text, the dance (where she incorporates her training in performance and ritual practices to invoke a light trance), and silent video, invoking Kantor's theories of the emballage (T. a. Kantor 259) by enacting the futile desire to capture that which was lost.

The perceptual shifts that produce effects like the difference note require conscious perception in different directions. Through this conscious perception, something else starts to emerge. This similar to the mechanism that occurs in states of ritual flow, where a conflation of time signatures combines with a conflation of sense stimuli, producing a unique hybrid that is experienced as embodied knowledge. Taking the cue from Watkins and Messe, "We propose that musicology stands to benefit from a material turn only if its purview includes both the materiality of the body and the complexities of embodiment as a phenomenon simultaneously mental and physical, rooted in the organic and routed through the cultural" (Watkins 161). The same material turn in theatre, both in terms of the phenomenology of the performer's experience and the phenomenology of the ghost, could start to answer the questions I have about the relationship between haunting and performing. In the next and final section, then, I offer some final reflections on how the living performer might live with this experience of embodiment, how it might be to live with awareness that we are haunted, and how, finally, to connect the metaphorical ghosts to the materiality of the dead.

\section{Moment Four: Physical Peak / Noon / Being Haunted}

$0000^{[26]}$

I started researching these ritual practices when I was in grad school in the early 1990s in the U.S. I went through a few initiatory rituals and ceremonies and had been to a couple of drums, but, for ten 
years, most of my learning was through books and journal articles. I met the godfather who would initiate me in Phoenix in 2005, through an auspicious chain of mutual connections. When I met him, I thought I knew lots of things.

He invited me to take part in a ceremony in his garage one day, and it was very hot, and there were people wearing white and singing and chanting. There were sounds and smells of chickens and goats; there was rum spraying and cigar smoke and sweet herbs, and I had a certain trembling feeling.

Similar to the moment in the garage with the prenda, when my body started to shake, these things, this knowledge, is in the body, and transmitted through the body. And I know it sounds corny, but words can't describe it; it's all in the doing. Being in contact with the dead, then, is more than believing in ghosts and more than honouring the memories of the dearly departed and more than getting messages from the other side. It's an embodied, living practice. My own contexts are in these traditions; there are many other traditions in the world where the dead are present, and in an ideal time they could be speaking to each other. Perhaps in a less than ideal time they could be speaking. Perhaps these conversations are happening already, and this could be a part of that.

Theatre for the Dead, then, is an approach, or an attitude, or the result of deep listening. It's a conversation between the dead and the living. If we are only talking to the dead, then all the issues of translation under neoliberalism are at play: this is a one-sided conversation where the ones who always talk are the ones who are still always talking. Theatre is a dialogue, and this means listening, and perhaps listening long enough that we might suddenly start becoming aware that the others, on the other side, outnumber us. To acknowledge the dead as spectators also means they are part of the body politic, indeed a material body that still matters. This is nothing new and hardly radical (just forgotten in certain circles in certain parts of the world, and certainly the one where I live now and the one where I lived before that). ${ }^{[27]}$ In Palo cosmology, the Kalunga line separates the living from the dead. The land of the dead is a mirror to this one; it's as complex and infinitely mysterious. The living can't cross over without dying; you don't become a citizen until you move there permanently. That there are technologies for facilitating conversations between the living and the dead suggests that there is a lot we have to say to each other and a lot to learn. When the living listen to the dead, they become haunted.

I am haunted. It will get worse as time goes on. The numbers keep rising. My body will shake and tremble, and something will want to come through, and the more I resist the worse it will get. The body counts get higher. Eventually we figure out that we have gotten sort of used to some of the things we've gotten used to. Eventually we find ourselves making something like theatre again, adapting to new given circumstances, we find ourselves wanting to make work that connects us, and on the best days, we find that the us is bigger than it was before.

Because we are haunted

Because every theatre has a ghost and because living with the dead is where hauntology starts. Because the past and the present are bound together epistemologically and ontologically.

Because the ephemeral fluctuations in the body are material, because the dead can speak through the body, because we know that feeling of getting so lost in the moment that it almost feels like something is moving through us.

Because we don't dance like no one's watching; we dance like we know the dead are watching. 
I finally propose one single simple thing: that we agree to stop seeing the dead as a metaphor.

"The disintegration of the system left its marks" (Glissant 72).

$+0+0 \frac{[28]}{20}$

\section{Works Cited}

Adorno, T. W. "The Curves of the Needle." October, 1990, pp. 48-55.

Adorno, T. W. The Culture Industry: Selected Essays on Mass Culture. Routledge, 1991.

Atwood, M. Negotiating with the Dead: A Writer on Writing. Virago, 2002.

Barker, H. Death, the One and the Art of Theatre. Routledge, 2005.

Baxter, A. J. "Challenging the myth of an 'epidemic' of common mental disorders: trends in the global prevalence of anxiety and depression between 1990 and 2010." Depression \& Anxiety, 2014, pp. 506-516.

Behrend, H. "Spaces of Refusal: Photophobic Spirits and the Technical Medium of Photography." Trance Mediums and New Media: Spirit Possession in the Age of Technical Reproduction. Fordham University Press, 2015, pp. 201-220.

Bell, K. The Magical Imagination: Magic and Modernity in Urban England, 1780-1914. Cambridge University Press, 2012.

Blau, H. Take Up the Bodies: Theater at the Vanishing Point. University of Illinois Press, 1982.

Brandon, G. Santeria from Africa to the New World: the Dead Sell Memories. University of Indiana Press, 1997.

Carlson, M. The Haunted Stage: Theatre as Memory Machine. University of Michigan Press, 2001.

Critchley, S. Stay Illusion!: The Hamlet Doctrine. Pantheon, 2013.

Curtin, A. Death in Modern Theatre: Stages of Mortality. Manchester University Press, 2019.

Danowski, C. The Medium and the Message: Afro-Cuban Trance and Western Theatrical Performance. University of Plymouth, PhD Dissertation, 2017.

Derrida, J. "Specters of Marx." New Left Review, 1994, pp. 31-58.

Diawara, M. Édouard Glissant's Worldmentality: An Introduction to One World in Relation, 2010. https://www.documenta14.de/en/south/34 edouard glissant s worldmentality an nntr. Accessed 8 August 2019.

Dolar, M. "I Shall Be with You on Your Wedding-Night': Lacan and the Uncanny." October, vol. 58, 1991, pp. 5-23.

Drewal, H. J. "Senses in Understanding of Art." African Arts, vol. 38, no. 2, 2005, pp. 1, 4, 6, 88, and 96.

Eliade, M. Myth \& Reality. Harper \& Row, 1963.

Fisher, M. "What Is Hauntology." Film Quarterly, 2012, pp. 16-24.

Fowokan. "Groundings \#4 (Decolonising the Archive)." London, 2018. 
Gallix, A. "Hauntology: A not-so-new critical manifestation." The Guardian, 17 June

2011. https://www.theguardian.com/books/booksblog/2011/jun/17/hauntology-critical. Accessed

22 January 2017.

Gilroy, P. The Black Atlantic: Modernity and Double Consciousness. Verso, 1993.

Glissant, É. Poetics of Relation. University of Michigan Press, 1993.

Hagglund, M. Radical Atheism: Derrida and the Time of Life. Stanford University Press, 2008.

Harding, F. "Soyinka and Power: Language and Imagery in 'Madmen and Specialists.'" African Theatre in Performance: A Festschrift in Honour of Martin Barnham, Edited by D. Layiwola, Routledge, 2013, pp. 103-116.

Harrison, G. W. Performance in Greek and Roman Theatre. Brill, 2013.

Hellier-Tinoco, R. "Dead Bodies/Live Bodies: Myths, Memory and Resurrection in Contemporary Mexican Performance." Performance, Embodiment, and Cultural Memory, Edited by C. Counsell, Cambridge Scholars, 2009, pp. 114-139.

Hong, J. Theatre of the Dead: A Social Turn in Chinese Funerary Art (1000-1400). University of Hawai'i Press, 2016.

Kane, B. Sound Unseen: Acousmatic Sound in Theory and Practice. University of Oxford Press, 2014.

Kantor, T. "The Theater of Death." Warszawa: Biblioteka Galeri Foksal, 1975. https://www.cricoteka.pl/pl/the-theatre-of-death/. Accessed 16 August 2019.

Kantor, T. A Journey through Other Spaces: Essays and Manifestos, 1944-1990. University of California Press, 1993.

Kompas, K. "Ghosts, living mix in 'Addams Family." S.C. Times. 28 January 2015. https://www.sctimes.com/story/entertainment/arts/2015/01/28/ghostly-horus takesspotlight-addams-family/22504469/. Accessed 5 March 2019.

Lacan, J. Écrits: The First Complete Edition in English. Norton, 2006.

Lippard, L. The Lure of the Local: Senses of Place in a Multicentered Society. New Press, 1997.

Mason, M. A. "'The Blood that Runs through the Veins': The Creation of Identity and a Client's Experience of Cuban-American Santería Dilogún Divination." The Performance Studies Reader, Edited by Henry Bial, Routledge, 2004, pp. 97-108.

Mounsef, D. "The Future of Performative: Staging the Body as Failure of the Archive." Global Performance Studies, vol. 2, no. 2, 2019, https://doi.org/10.33303/gpsv2n2a4

Ochoa, T. R. "Versions of the Dead: Kalunga, Cuban-Kongo Materiality, and Ethnography." Cultural Anthropology, 2007, pp. 473-500.

Ochoa, T. R. Society of the Dead: Quita Manaquita and Palo Praise in Cuba. University of California Press, 2010.

Otero, S. Yemonja: Gender, Sexuality, and Creativity in the Latina/o and Afro-Atlantic Diasporas. State University of New York Press, 2014. 
Phelan, P. Unmarked: The Politics of Performance. Routledge, 1993.

Rayner, A. Ghosts: Death's Double and the Phenomena of Theatre. University of Minnesota Press, 2006.

Roach, J. Cities of the Dead: Circum-Atlantic Performance. Columbia University Press, 1996.

Russom, R. Personal Interview by C. Danowski. 30 August 2015.

Russom, R. Personal Interview by C. Danowski. February 2019.

Russom, R. "Black Meteoric Star - Ghost Frequency EP." Black Meteoric Star, 26 April

2019. https://soundcloud.com/blackmeteoricstar/sets/black-meteoric-star-ghost. Accessed 24 August 2019.

Schechner, R. Performance Studies: An Introduction (Second Edition). Routledge, 2002.

Schmidt, B. "Meeting the Spirits: Puerto Rican Espiritismo as Source for Identity, Healing and Creativity." Fieldwork in Religion, 2008, pp. 178-194.

Sharpe, C. In the Wake: On Blackness and Being. Duke University Press, 2016.

States, B. O. Hamlet and the Concept of Character. Johns Hopkins University Press, 1992.

Stengers, I. "Reclaiming Anamism." e-flux, \#36, 2012. https://e-

flux.com/journal/36/61245/reclaiming-animism/. Accessed 10 June 2019.

Taylor, Diana. The Archive and the Repertoire. Duke University Press, 2003.

Tedlock, D. Rabinal Achi: A Mayan Drama of War and Sacrific. Oxford University Press, 2005.

Thompson, R. F. Flash of the Spirit: African and Afro-American Art and Philosophy. Vintage, 1984.

Underiner, T. Contemporary Theatre in Mayan Mexico: Death-Defying Acts. University of Texas Press, 2004.

Valencia, S. “Capitalismo Gore.” Debate Feminista, 2014, pp. 51-76.

Vivieros de Castro, E. Cannibal Metaphysics. University of Minnesota Press, 2014.

Walter, T. "Communication media and the dead: from the Stone Age to Facebook." Mortality, vol. 20, no. 3, pp. 215-232.

Watkins, H. A. "Down with Disembodiment: Musicology and the Material Turn." Women and Music, 2015, pp. 160-168.

Ybarra, P. A. Latinx Theater in the Times of Neoliberalism. Northwestern University Press, 2018.

\section{Endnotes}

[1] These ideas came out of conversations and performance projects made with Bethanne Abramovich, Portia Beacham, Boyd Branch, Jamie Haas, Heather Lee Harper, Erika Hughes, Jake Jack Hylton, Beth May, Liana O'Boyle, Seth Scott, and Jake the Dog between 2013 and the present. These performances came about, in part, through a methodology I have been developing involving ritual practices invoking ancestors for the co-creation of creative work. This will be discussed further, but while you're here, in the endnotes, let me start to explain the conceit of these endnotes. Metaphorically, the endnotes act as a mirror to the main text, albeit a distorted mirror. In some 
ritual traditions (the specifics of which will be discussed further), the world of the living is separated from the world of the dead metaphorically as a water line. In Palo, a Kongo-descended practice that moved from Cuba to the "New World," this line is called the Kalunga line. These endnotes, on the dead side of the Kalunga line, both serve the traditional academic function of endnotes, but they also only include those thoughts, names, concepts, who have a deeper connection to the dead than to the living. These endnotes contain traces of the text of the manifesto, just as the words in the manifesto can be conceived of as containing traces of these notes, just as the living carry traces of the dead because "the attitudes toward what constitutes a bounded being are fluid" (Otero 96); there is a fluidity in the discourse, although generally speaking the idea is that the manifesto text is in the world of the living, and the endnotes are the world of the dead, layers of sediment to give the ground stability.

[2] "Theatre can help us to fulfil a psychological - and maybe a spiritual - need to connect to the dead" (Curtin 4). This will perhaps be obvious, or innovative, or perhaps even come as good news, depending on where and when one is in the world.

[3] Glissant's imaginary (as opposed to Lacan's) is how a culture perceives and conceives the world (Glissant xxii).

[4] There are multiple references in the literature to this cosmogram, but it obviously comes from practices that go back much further than 1974 and has been passed down primarily in oral ritual traditions. This is probably an obvious point, but needs repetition, that this is an ongoing problem in the west with citational practices when dealing with ritual traditions: some ideas do come from the dead, some with names that the living remember, and some with names who have been forgotten. Marking this below the metaphorical Kalunga line in the endnotes is an attempt to denote those ideas that come with a long list of dead authors who cannot necessarily be named by name but should be marked with these marks.

[5] In Palo Monte ritual practices, this cosmogram is a useful map for both the dead and the living and doesn't privilege one over the other.

[6] In keeping with the conceit, for the above and below in terms of these endnotes, each of the four sections is accompanied by a divination pattern. In Lukumí, it's with obi, four discs of fresh coconut, and in Palo the discs are from the dried shell and called chamalongos. The divination comes through throwing the pieces to the ground and counting the sides that are white vs. the sides that are dark, and each of these (potentially five) patterns, reveals something. Using a format that is standard in tratados (librettos that contain instructions for ritual practices), I'm using + to indicate dark, and o to indicate light. Here, the pattern is four dark, called Oyekun; the most negative response to any question in divination, and also signifies utter darkness.

[7] Crossroads and intersections are both hot points in Lukumí and Palo cosmologies. In Yorubadescended practices this space is related to Eleggua, the trickster Orisha, who controls physical and metaphorical places "where doors open or close, where persons have to make decisions that may forever after affect their lives" (Thompson 19).

${ }^{[8]}$ The Kalunga line, as mentioned above, is from Palo cosmology, the literal and metaphorical water mark separating the world of the living from the world of the dead. Although there are attributes of the living and the dead that are obviously absolute, in ritual practice the line is porous: "Her elaboration of Kalunga dissolved the expected opposition of living and dead so that not only did these two great ordering categories no longer stand in opposition to one another, but at the limit of her characterizations became an indivisible coupling, mutually becoming one another at their limits. 
Placed within the context of Kalunga's saturating immanence, the living are best understood as singular densities of the dead coagulating in a fluid at its saturation point" (Ochoa, Versions of the Dead: Kalunga, Cuban-Kongo Materiality, and Ethnography 484).

[9] "To paraphrase Glissant, we must not surrender to the partitioning of the world nor to irreconcilable differences, binary divisions, opposition of species, and genres. We must fight the desire to divide ourselves into threatening diversities, which remove any sense of poetry and imaginary from our differences. The sparkle of truth and reality must not be isolated from the darkness and opacity out of which they emerge" (Diawara).

[10] Tamara Underiner, when discussing Victor Turner in her book on contemporary Mayan theater, writes that theater "almost always occupies a liminal space as well, a space marked off for the special purpose of the performance - a space removed (or transformed) from everyday life but not quite resident in the realm of the divine" (Underiner 4). Full disclosure that we have a child together, and were living in Chiapas in 1996, when she was researching for her doctoral dissertation. Some of my thoughts on performance and ritual were inspired by work with Tzeltal and Tzotzil-speaking theatre collectives Sna Jtz'ibajom and La FOMMA in Chiapas, Yucatecan Mayan Teatro Comunitario in Yucatán, and Laboratorio del Teatro Campesino y Indigena's work with Chontal-speaking communities in Tabasco. Although there were many instances where the connection with the ancestors was apparent or explicit, these communities are, of course, not at all homogenous, with complexities far beyond the scope of this or any discursive exercise.

[11] My notion of hauntology is inspired by the notion of the "difference tone," as elaborated by Rayna Russom, where one sound plays through one ear, another sound plays through the other, causing the listener's consciousness to engage and create a sound that somehow makes sense of both sounds (Russom, 30 August 2015). This isn't actually created by the music, but inside the listener's own head. Elaborating this metaphor into theatre practice, there is a space between character and actor, and performer and projection, and that space only comes to life in juxtaposition. I'll talk about this more in the third moment.

[12] "And past. In popular practices of remembrance, the dead continue to exist alongside the living, and the dead are simultaneously 'on stage' with the living. The dead, who represent and are memory, preserve the past alongside the living, serving to provide a collective memory threatened by extinction through the dislocations of modernization in postrevolutionary Mexico. Indigenous bodies become objects of the past, embodying the 'souls of the ancestors,' hinting at notions of immortality, and enabling a trace and residue of preincursion Mexico. Bodies of living individuals are transformed into the 'soul' of Mexico in a representation and remembering of the collectivity of the Mexican nation. In a century of loss of soul through modern alienation, engaging with indigenous bodies and with performances that connect to prehispanic bodies generates compelling sites of cultural memory" (Hellier-Tinoco 121).

[13] Also note that "The dead get blood [...] they are assumed to be hungry and thirsty" (Atwood 159).

[14] For just a few historical examples, consider funerary processions in ancient Rome when actors were hired to perform as the dead, and valued for their resemblance and abilities to evoke verisimilitude (Harrison 380). Jeehee Hong theorises that elements of Chinese funerary art from the eleventh though the sixteenth centuries can be interpreted as having performative and theatrical functions whose audience was the dead (Hong). Dennis Tedlock's translation work and scholarship on the Rabinal Achi (Tedlock) from pre-Columbian Mayan culture in Guatemala suggests that the actors who perform the play are inhabited by the original ancestors who performed in the original 
production. These aren't the only examples, of course, of the dead embodied by the living in performance. It may not be quotidian, but it is also not unique.

[15] "Death desires us and to desire is to face up to death" (Critchley 133).

[16] This recalls Carlson's notion of ghosting, and he also points out how Kantor literally haunted his own production. In his final work, "Today is My Birthday," Kantor died during rehearsals, and his iconic chair was left on stage, empty, during the run of the Krikot performances (Carlson 105).

[17] Again, it seems a mistake not to mention that moment of writing, in the spring of 2020, when to all appearances, globally we are walking into that future; the one that didn't happen all of a sudden did. In this moment, we are not only haunted by the future that has been delayed but haunted by the recent dead lost to the virus, those lost from other causes who had to die alone, and also those who are not yet showing symptoms or are even infected yet.

[18] This is Okana, and in a divination, where there are yes or no questions, the answer here would be no. A skilled diviner could conceivably turn this to a yes, but the general idea here is that there is more darkness than light, more unknown than known.

[19] The prenda in Palo practice is a container for "the Kongo cosmos in miniature" (Thompson 121).

[20] "(What took place in the Caribbean, which could be summed up in the word creolization, approximates the idea of Relation for us as nearly as possible. It is not merely an encounter, a shock (in Segalen's sense), a métissage, but a new and original dimension allowing each person to be there and elsewhere, rooted and open, lost in the mountains and free beneath the sea, in harmony and in errantry" (Glissant 59).

[21] "In Palo, the living are condensations of Kalunga, the ambient dead, and are easily transformed. In possession, the living pass from being a version of the ambient dead to being a version of the responsive dead and back again" (Ochoa, "Society of the Dead: Quita Manaquita and Palo Praise in Cuba"). This is to say that the categories are useful but also absolutely fluid, as in Palo practice, the prenda, which serves as a home for an initiate's specific muerto, is particular in identity but not necessarily stable. The prenda, "and the dead it collects, can become many versions of itself simultaneously" (Ochoa, Society of the Dead: Quita Manaquita and Palo Praise in Cuba).

[22] In the soapmaker's house, everyone slips.

[23] See also Vivieros de Castro's "practice of the permanent decolonization of thought" (Vivieros de Castro).

[24] "Everything you know and strive to know was already known to the dead - or is known to them. Are we diminished by this?" (Barker 19)

[25] This is Etawa, with three light and one dark. It can be a yes, but it's an unstable yes and would usually require another throw to verify. I usually take it to mean either "everything is fine, stop asking," or "could be better but this acceptable." More light than dark.

[26] This is Alafia. All light, all is revealed, and this is very positive. However, like the noonday sun, there is no shadow here, which can indicate a refusal on the part of the querent to see only "the bright side" and to miss the nuance.

[27] By these circles I'm referring in general to a primarily English-speaking academic world. I would suggest that these circles' shared scepticism toward a living relationship with the dead comes from a 
kind of cultural amnesia, and that coming face to face with the dead also means coming face to face a lot of ghosts.

${ }^{[28]}$ Eyeife: two light and two dark. World in balance. Best possible outcome. World of the living and the world of the dead are in agreement. 